\title{
Analysis of the Organizational Aspects of a Clinical Emergency Department: A Study in a General Hospital in Ribeirao Preto, SP, Brazil ${ }^{1}$
}

\author{
Mônica Franco Coelho \\ Lucieli Dias Pedreschi Chaves ${ }^{3}$ \\ Maria Luiza Anselmi ${ }^{4}$ \\ Miyeko Hayashida ${ }^{5}$ \\ Claudia Benedita dos Santos ${ }^{6}$
}

Demand for the Emergency Department (ED) has increased, making the organization of work difficult. This quantitative, descriptive and documental study identifies and analyzes the characteristics of clinical care in the ED of a General Hospital in Ribeirão Preto, SP, in 2007, according to organizational variables. The study population included all clinical care consultations registered in the Hospital Management Information System. Data were analyzed through descriptive statistics and discussed considering the theoretical framework of the Single Health System (SUS). A total of 5,285 consultations were registered in the period, which were more frequent in patients from the city itself, in January $(10 \%)$, on Mondays (16\%), from $12 \mathrm{pm}$ to $12 \mathrm{am}(67.1 \%)$. The main reason for discharge from the unit was hospitalization (63.8\%) and the predominant length of stay in the unit was less than six hours (39.8\%). The results support the management of human resources, materials and equipment, indicating the desirability of reorganizing emergency care in the hospital.

Descriptors: Nursing; Emergency Medical Services; Organization and Administration.

\footnotetext{
${ }^{1}$ Paper extracted from Master's Thesis "Caracterização dos atendimentos de urgência clínica em um hospital de ensino" presented to Programa de Pós Graduação em Enfermagem Fundamental, Escola de Enfermagem de Ribeirão Preto, Universidade de São Paulo, WHO Collaborating Centre for Nursing Research Development, SP, Brazil.

${ }^{2}$ RN, Hospital da Unimed de São Carlos, SP, Brazil. Professor, Centro Universitário Central Paulista, SP, Brazil. Master's Student, Programa de Pós Graduação em Enfermagem Fundamental, Escola de Enfermagem de Ribeirão Preto, Universidade de São Paulo, SP, Brazil. E-mail: nikinha83@yahoo.com.br.

${ }^{3}$ RN, Ph.D. in Nursing, Professor, Escola de Enfermagem de Ribeirão Preto, Universidade de São Paulo, SP, Brazil. E-mail: dpchaves@eerp.usp.br.

${ }^{4}$ RN, Ph.D. in Nursing, Retired Professor, Escola de Enfermagem de Ribeirão Preto, Universidade de São Paulo, SP, Brazil. E-mail: anselmi@eerp.usp.br.

${ }^{5}$ RN, Ph.D. in Nursing, Escola de Enfermagem de Ribeirão Preto, Universidade de São Paulo, SP, Brasil. E-mail: miyeko@eerp.usp.br.

${ }^{6}$ Ph.D. in Statistics, Associate Professor, Escola de Enfermagem de Ribeirão Preto, Universidade de São Paulo, SP, Brasil. E-mail: cbsantos@eerp.usp.br.
}

Corresponding Author:

Lucieli Dias Pedreschi Chaves

Universidade de São Paulo. Escola de Enfermagem de Ribeirão Preto

Av. Bandeirantes, 3900

Bairro Monte Alegre

CEP: 14040-902 Ribeirão Preto, SP, Brasil

E-mail: dpchaves@eerp.usp.br 


\section{Análise dos aspectos organizacionais de um serviço de urgências clínicas: estudo em um hospital geral do município de Ribeirão Preto, SP, Brasil}

A demanda por serviços de urgência e emergência tem aumentado, dificultado a organização do trabalho. Com o objetivo de identificar e analisar características dos atendimentos de clínica médica, no serviço de urgência de hospital geral em Ribeirão Preto, 2007, segundo variáveis organizacionais, foi realizado estudo quantitativo, descritivo, utilizando dados documentais. A população de estudo foi representada por todos os atendimentos clínicos, registrados no Sistema de Informação Gestão Hospitalar. Os dados foram analisados segundo estatística descritiva e discutidos considerando o referencial teórico de reorganização do SUS. No período, ocorreram 5285 atendimentos, que foram mais frequentes em pacientes procedentes do próprio município, no mês de janeiro $(10 \%)$, às segundas-feiras $(16 \%)$, horário das 12 às $24 \mathrm{~h}(67,1 \%)$, principal motivo de alta da internação hospitalar $(63,8 \%)$ e o tempo de permanência na unidade, predominante, foi inferior a seis horas $(39,8 \%)$. Os resultados subsidiam gerenciamento de recursos humanos, materiais e equipamentos, favorecendo reorganização do microespaço de atenção à urgência no hospital.

Descritores: Enfermagem; Serviços Médicos de Emergência; Organização e Administração.

\section{Análisis de los aspectos de organización de un servicio de urgencias clínicas: estudio realizado en un hospital general del municipio de Ribeirao Preto, SP, Brasil}

La demanda por servicios de urgencia y emergencia ha aumentado, dificultado la organización del trabajo. Con el objetivo de identificar y analizar las características de las atenciones de clínica médica, en el Servicio de Urgencia del Hospital General en Ribeirao Preto, 2007, según las variables de organización fue realizado este estudio cuantitativo y descriptivo, utilizando datos documentales. La población de estudio fueron todas las atenciones clínicas, registrados en el Sistema de Información de Gestión Hospitalaria. Los datos fueron analizados según la estadística descriptiva y discutidos considerando el referencial teórico de reorganización del SUS. En el período ocurrieron 5.285 atenciones que fueron más frecuentes en pacientes procedentes del propio municipio $(63,8 \%)$, en el mes de enero (10\%), los días lunes (16\%), en el horario de la 12 a las $24 \mathrm{~h}(67,1 \%)$, y el tiempo predominante de permanencia en la unidad fue inferior a seis horas (39,8\%). Los resultados ofrecen subsidios para mejorar la gestión de recursos humanos, materiales y equipamientos, favoreciendo la reorganización del micro espacio de atención de urgencia en el hospital.

Descriptores: Enfermería; Servicios Médicos de Urgencia; Organización y Administración.

\section{Introduction}

The appropriate supply of primary health care is a relevant factor in avoiding the delivery of hospital care when outpatient care would suffice; it is necessary to organize the care network in order to improve articulation among the different spheres of care(1).

Ensuring care to a historically unattended population and at the same time implementing networks that can fully meet the health needs of users is the current challenge presented to health services(2).

From this perspective, urgent and emergency services have peculiarities and specificities that have been the object of study worldwide with special focus 
on issues related to the increased demand and use of this level of care, both in private and public services demonstrating problems related to infrastructure and the organization of services, quality of care, quantity and specificity of care provided and its main social consequences $^{(3)}$.

Even today, health policies grounded on its main laws and directives are not sufficient to alter the large demand for this type of service. The situation escalates due to demographic alterations, increase in non-transmissible chronic diseases, increased violence and unemployment, worsened living conditions, misuse of public money, all of which culminate in a growing dissatisfaction of users and health services workers $^{(4)}$.

In particular, the care delivered in urgent and emergency situations should be planned, programmed and put into operation so as to comply with SUS principles. However, due to deficiencies in the local health system, these services end up being the doorway to hospitals, representing for users a possibility of having access to more complex care with a greater problem-solving capacity(5).

For the appropriate use of the different levels of complexity of the health system, it is necessary to establish a regionalized flow to meet the needs of users in an organized manner. Nonexistent or inappropriate flow, duplication of services to meet the same end and easy access to levels of higher complexity generate distortions that compromise the principles of integrality*, universality, equity and rational expenditure ${ }^{(6)}$.

The enlarged demand for urgent and emergency services generates disorganization within the unit, low quality care, unnecessary expenses, resulting in an inefficient use of available resources. It also has repercussions for the guarantee of citizen rights, particularly in relation to access to health services. Seeking to solve the problem of care in the urgent and emergency field, some measures have been taken by the government in recent years ${ }^{(7)}$.

In Brazil, the initial milestone is the program created by the Ministry of Health (MH) in 1990 to Cope with Emergencies and Traumas. Its aim is to reduce incidences, morbidity and mortality due external negative health conditions, at the time considered the third leading cause of death in the country. It is possible to find standards regarding the different means of transportation, care according to the complexity of cases, organization of the hospital and pre-hospital care system and also the medical regulation of emergencies. In 2002, the $\mathrm{MH}$ issued Directive No. 2048 that provides the technical regulation of state emergencies and emergency systems, establishing principles, guidelines, criteria and functioning standards and registration in these services. This directive also provides standards regulating fixed and mobile pre-hospital medical care, hospital care, interhospital transportation and the creation of permanent educational centers ${ }^{(8)}$.

Even today, despite the time-elapsed and structuring initiatives, it is still necessary to acknowledge that the Brazilian emergency care system is under construction and the axis of departure for its organization is the diagnosis of a population's needs based on health indicators and data regarding morbidity and mortality of a given geographic area(8).

Analyzing the demand for care focusing on organizational aspects, especially in the hospital sphere, is an important source of information that can support the process of meeting demands, enabling the characterization of the profile of cases cared for in the service, providing support to nurses to develop routines and strategies for more adequate human and technology resources in order to meet the needs of users. This analysis can also be used as an instrument to ordinate the care and managerial work of the remaining professionals of the health team, both in the hospital setting and in the local health system.

The work of nurses in the emergency department involves specificities and necessary interaction with care management for patients with complex needs, requires scientific improvement, technological management and extensive humanization for family members, which has expressive representations in the work process of this professional. Its importance is not only due to the complexity and particularities of caring actions, but also to the material and human resources that are mobilized, in addition to the need to interface with other sectors in the hospital and the local health system.

A careful bibliographic search was carried out in the Latin American and Caribbean Health Sciences (LILACS) database and the Brazilian Portal of Scientific Information of the Coordination of Improvement of Higher Level Personnel (CAPES) database for

\footnotetext{
* Integrality refers to the idea that individuals are historical, social and political subjects and should be considered as a whole during the care delivery process. It also assumes that health care actions should be combined and focused on health promotion, prevention and healing.
} 
publications between 1988 and 2009, using the descriptor emergency medical services. A total of 781 potential references were identified, of which only one addressed clinical emergencies, evidencing the scarcity of investigation in the field.

Recent studies ${ }^{(7,9-14)}$ addressing hospital and prehospital urgent and emergency care are worth noting, though, none is related to the characterization of care demand or the organizational aspects of these services. It is expected that the results of this study will support the management of human, material and equipment resources favoring the reorganization of care of the micro space of care within the hospital emergency services and to support the process of nursing education.

In line with the preceding discussion, we ask: what is the profile of care delivered in the clinical medical specialty of the emergency department of a university general hospital in Ribeirão, SP, Brazil considering organizational variables of origin, unit of origin, month, day of the week, time of arrival, discharge motive, duration of stay in the unit and unit of destination in 2007?

From this perspective, a study was developed to identify and analyze the characteristics of visits in the clinical medical specialty in the emergency department of a university general hospital in Ribeirão Preto, SP, Brazil in 2007 according to organizational variables.

\section{Material and Method}

This is a descriptive study that uses documental data. It was developed in Ribeirão Preto, located in the northeast of state of São Paulo, $313 \mathrm{~km}$ from the capital. It is the main city in the region and a commercial and services center, especially in the health field.

An Emergency Medical Care Unit (SAMU) was implemented in Ribeirão Preto in 1996. Then, a control facility, the Single Center of Medical Regulation, was implemented in 1999 to organize the flow of patients to the local health services in urgent and emergency situations.

The study's setting was the emergency department of a university general hospital that covers clinical care, respiratory isolation, clinical stabilization room (CSR), traumatic emergencies (politrauma), orthopedics and gynecological care. The clinical care sector was studied field. It has three offices and 14 beds for clinical observation.

The study's population includes all the visits to the emergency clinical care sector between January $1^{\text {st }}$ and December $31^{\text {st }} 2007$ and registered in the information and hospital management system (SIGH). The following inclusion criteria were used: adult patients receiving care in the clinical care sector in the study period and who stayed under observation. The exclusion criteria were: clinical care in pediatrics, psychiatrics, gynecology, orthopedics, and clinical consultations to adult patients who did not need to stay for observation. In this study we consider a clinical consultation to be a set of care actions developed with the patient while in the emergency service including medical consultation, diagnosis, therapeutic and care procedures.

This documental study used secondary data originating in the $\mathrm{SIGH}$, a program developed by the Data Processing Company of the State of São Paulo (PRODESP) to manage hospital information. Data were obtained from the patients' file and were transformed into statistical reports and stored in a database in the studied facility. Based on these reports, a spreadsheet was developed in MS Excel including all consultations carried out in 2007. The variables of interest in this study were: city of origin, health unit of origin, CID-10 of discharge from the emergency room, time, day of the week and month of arrival at the service, length of stay in the unit, motive of discharge after consultation, and unit of destination. This set of variables allows determining the characteristics of users cared for in the service and the intra-hospital organizational aspects related to the knowledge of clinical emergencies.

Data were stored in an MS Excel ${ }^{\circledR}$ spreadsheet and transferred to the Epi-Info 3.5.1, then the statistical analysis of descriptive data was presented in frequencies and percentages. The discussion was developed based on the adopted theoretical framework concerning reorganization of clinical urgent/emergency care in the local health system sphere from the perspective of the SUS.

The study was developed so as to comply with Resolution 196/96(15) concerning research involving human beings. It was submitted to and approved by the Ethics Research Committee at the studied hospital through the Clinical Research Unit (process $n^{0}$ $3863 / 2008)$. It was also registered with the National Committee of Ethics Research (CONEP).

\section{Results}

The results are presented in two tables in a descriptive/quantitative way considering the variables involved. 
Table 1 - Distribution of visits, specialty of medical clinical in the ED of a university hospital according to origin, unit of origin, month, day of the week and time of arrival, 2007, Ribeirão Preto, SP, Brazil

\begin{tabular}{|c|c|c|}
\hline Variables & $\mathbf{N}$ & $\%$ \\
\hline \multicolumn{3}{|l|}{ Origin } \\
\hline Ribeirão Preto & 3367 & 63.7 \\
\hline DRS XIII (except Ribeirão Preto) & 1390 & 26.3 \\
\hline Others cities in São Paulo & 153 & 2.9 \\
\hline Cities of other states & 45 & 0.8 \\
\hline No information & 330 & 6.2 \\
\hline Total & 5285 & 100 \\
\hline \multicolumn{3}{|l|}{ Unit of Origin } \\
\hline Hospital das Clinicas Campus & 274 & 5.2 \\
\hline BHU Ribeirão Preto & 1888 & 35.7 \\
\hline Other units & 944 & 17.9 \\
\hline No information & 2179 & 41.2 \\
\hline Total & 5285 & 100 \\
\hline \multicolumn{3}{|l|}{ Month } \\
\hline January & 529 & 10.0 \\
\hline February & 434 & 8.2 \\
\hline March & 438 & 8.3 \\
\hline April & 436 & 8.2 \\
\hline May & 417 & 7.9 \\
\hline June & 396 & 7.5 \\
\hline July & 468 & 8.9 \\
\hline August & 404 & 7.6 \\
\hline September & 425 & 8.0 \\
\hline October & 443 & 8.4 \\
\hline November & 404 & 7.6 \\
\hline December & 491 & 9.3 \\
\hline Total & 5285 & 100 \\
\hline \multicolumn{3}{|l|}{ Day of the week } \\
\hline Sunday & 669 & 12.7 \\
\hline Monday & 844 & 16.0 \\
\hline Tuesday & 742 & 14.0 \\
\hline Wednesday & 817 & 15.5 \\
\hline Thursday & 739 & 14.0 \\
\hline Friday & 776 & 14.7 \\
\hline Saturday & 697 & 13.2 \\
\hline No information & 1 & 0.02 \\
\hline Total & 5285 & 100 \\
\hline \multicolumn{3}{|l|}{ Time of Arrival } \\
\hline 12am $+6 a m$ & 581 & 11.0 \\
\hline $6 \mathrm{am}+12 \mathrm{pm}$ & 1161 & 22.0 \\
\hline $12 \mathrm{pm} \vdash-6 \mathrm{pm}$ & 1922 & 36.4 \\
\hline $6 \mathrm{pm} \vdash 12 \mathrm{am}$ & 1621 & 30.7 \\
\hline Total & 5285 & 100 \\
\hline
\end{tabular}

The results show that of $63.7 \%$ of visits are carried out with patients from the city of Ribeirão Preto and $26.3 \%$ are from other cities from the DRS XIII, evidence that regionalization seems to be functioning appropriately in the SUS referral system. The hospital's level of complexity might explain the $3.7 \%$ of visits originating from other cities in the state and other states, since the magnitude of material and human resources available in the studied ED are considered excellent for cases of higher complexity, a draw for patients from areas outside the city.

Not only the city of origin, but also the unit of origin are important in categorizing the flow of patients in the system. The results of this study indicate incomplete data has been included in the SIGH because they show that in $41.2 \%$ of cases, the unit of origin is not reported, while $35.7 \%$ are from basic health units of Ribeirão Preto. It is worth noting that patients cared for in this service are necessarily referred by other health units.

The month of the year when the visits took place presented little variation. January was the month with highest frequency of visits (10\%) and December the lowest $(9.3 \%)$. This information suggests there is not an expressive variation in visits due to seasonal factors.

There was some variation in relation to day of week, with a higher concentration on Mondays and Wednesdays, $16.0 \%$ and $15.5 \%$, respectively and a smaller number of visits on Sundays, $12.7 \%$. We hold that this result should guide managerial resources and provision of material appropriate to mirror the demand.

The period of the day with the greatest number of visits was from $12 \mathrm{pm}$ to $6 \mathrm{pm}$ (36.4\%) and from $6 \mathrm{pm}$ to $12 \mathrm{am}(30.7 \%)$. These periods differed in the number of visits if compared to the remaining periods shown in Table 1. This is important information for the organization of the team's daily work schedule, in that the unit that should concentrate the highest number of professionals on the schedule in these periods when demand is at its highest.

The following characteristics of visits of the studied specialty of the medical clinic were tabulated: motive of discharge, length of stay in the unit and unit of destination.

Table 2 - Characteristics of visits, specialty of the medical clinic in the ED of a university hospital according to the motive of discharge, length of stay in the unit and unit of destination in 2007, Ribeirão Preto, SP, Brazil

\begin{tabular}{lcc}
\hline \multicolumn{1}{c}{ Variables } & \\
\hline Motive of discharge & 3374 & 63.8 \\
Hospitalization & 1683 & 31.8 \\
Medical discharge & 70 & 1.3 \\
Death <24 h & 46 & 0.9 \\
Referred to outpatient & 25 & 0.5 \\
Sheet did not returned to SAME & 28 & 0.5 \\
Referred to BHU & 35 & 0.7 \\
Abandonment. Evasion & &
\end{tabular}

Continue... 
Table 2 - Continuation

\begin{tabular}{lcc}
\multicolumn{1}{c}{ Variables } & & \\
\hline Discharge request & 7 & 0.1 \\
Referred to other hospitals & 17 & 0.3 \\
Total & 5285 & 100 \\
Length of stay (hours) & & \\
<6am & 2105 & 39.8 \\
06am F 12pm & 871 & 16.5 \\
12pm F-6pm & 466 & 8.8 \\
6pm F 12am & 352 & 6.7 \\
$\geq 12 a m$ & 1448 & 27.4 \\
Not specified & 43 & 0.8 \\
Total & 5285 & 100 \\
Unit of destination & & \\
Hospital das Clinicas - ED & 2348 & 44.4 \\
HC Campus & 201 & 3.8 \\
No information & 2736 & 51.8 \\
Total & 5285 & 100 \\
\hline
\end{tabular}

The most frequent reason for discharge was hospitalization $(63.8 \%)$, while the large number of hospitalizations is something expected given the service characteristics. The care provided to the most severe patients requires the availability of beds for hospitalization for continuing with care. The patient is admitted to the $E D$, is stabilized in the first hours and is referred to another sector for treatment follow-up. However, 31.8\% of the visits resulted in medical discharge, which raises the question whether referrals are being appropriately made in the service.

The variable length of stay might be an indication of the cases' complexity, the appropriateness of referrals to urgent and emergency services, and the service's problem-solving capacity. In this study, $39.8 \%$ of patients stayed for less than six hours and $27.4 \%$ between 24 and 30 hours in the service. It is worth noting that even though physical facilities have good sanitary conditions, they are not appropriate for patients' prolonged stay, since they do not provide satisfactory comfort or hospitality.

In $51.8 \%$ of the cases, no records were found in the documents regarding the patients' unit of destination, indicating another aspect that is not properly recorded in the SIGH database. In $44.4 \%$ of the visits, patients are hospitalized in the hospital where ED care was provided. The lack of records relating to patients' discharge could be due to a lack of the local preparedness to acknowledge the importance of such records, which is a fact that hinders the analysis of patient flow after care is provided in urgent and emergency units and that compromises deep analysis concerning the outcome of urgent care in medical clinics in the local health system.

\section{Discussion}

The need for rational and adequate use of human, material and financial resources at each level of care has encouraged a discussion concerning the participation of the hospital in the health system. The increased demand for health services, especially in hospital urgent and emergency units, requires the adoption of strategies on the part of governments, institutions and professionals to update local health systems within the guidelines of the National Policy on Urgent Care and SUS.

The causes that lead to the increased demand for urgent and emergency care are diverse. They reflect social, epidemiological and cultural issues, in addition to aspects related to the health system organization.

Urgent and emergency care aims to re-establish vital parameters of individuals and, therefore, requires professionals to be appropriately qualified, with materia and equipment rapidly available to anticipate care. Moreover, the specificities that differentiate a given organization from the remaining health services as it receives patients from several health units with clinical conditions of varied complexity, in different specialties, must be considered. In addition to the aspects related to health care, given that care is provided around the clock and that there are failures in the local health system organization, it becomes a service with facilitated access and bears a demand that could be resolved at another level of hospital care.

Nurses in particular should seek new instruments to organize their work in order to promote improved nursing care, in addition to encouraging the appropriate use of human and material resources to meet the needs presented by users. From this perspective, knowing the socio-demographic and epidemiological profile of users in the scope area in which the health service is located and how it interacts with other spheres of health care within the SUS is very important. Nurses in urgent and emergency care, in addition to directly participating in care, also have to make material and human resources available, enabling an organization of care that balances demand and necessary resources.

The identification of city of origin and unit of origin for patients allows the characterization of the flow of health system users, favors the diagnosis of potential distortions, as well as evaluates of the relevance of referrals to a hospital service of high complexity. Hence, it is possible to program improvements and qualifications of teams from units and cities of origin to improve their problem-solving capacity within the health system itself. 
In relation to origination, the results of this study evidenced that most of the visits occurred from patients originating from Ribeirão Preto. It is interesting to note that other studies also indicate that most of the visits to urgent/emergency care refer to patients in the city in which the studied hospital is located ${ }^{(4,16-18)}$.

Hierarchy and regionalization, organizational principles of the SUS, aim to reorganize the system in order to see health needs and demands in detail. Reorganization based on these principles also provides the necessary resources for a given coverage area, with a view to facilitate access and more homogeneously allocate resources. It is desirable that users seek out qualified care services in quality health units in their area or near where they live for more comfortable access and to ease the burden on more complex units ${ }^{(19)}$. It is necessary that users needing urgent and emergency care be referred to such services in order to facilitate the organization of the service and tailor the care provided.

In regard to the distribution of visits according to the months of the year, we verified that the month of greatest visitation to the ED was January and the month with the least visits was November, $10 \%$ and $7.3 \%$ respectively, of visits in the studied period. The results of other studies evidenced variation in the months of the year; it is supposed that such a situation is the result of regional and seasonal variations that interfere in the pattern of diseases and respective visits of population(16-18).

A higher demand was identified on Monday (16\%), which corroborates other studies' results that also indicate that the highest demand occurs on this day of the week ${ }^{(17-18)}$. These authors stress that it is possible the higher demand evidenced on Mondays is a consequence of the accumulated visits generated during the weekend, when a diminished supply of health services is available, causing SUS users to look for urgent and emergency care to solve their health problems, when altered routines occur in individuals' lives.

The study identified that $67.1 \%$ of the visits occurred between $12 \mathrm{pm}$ to $12 \mathrm{am}$. A similar result was found in other studies ${ }^{(16-18)}$.

The main reason for discharge in the studied service was hospitalization. Such results imply that the majority of visits needed actually to be referred for hospital care, since in addition to urgent and emergency care, there was a need to continue treatment at a hospital level.

In contrast, $31.8 \%$ of the visits generated medical discharge right after consultation, what leads us to wonder why users sought out the unit in the first place, since an urgent or emergency consultation held in a hospital of high complexity is not expected to end up with the patient's immediate discharge, with no continuity of treatment. This result indicates that new investigations are needed in order to clarify such facts.

It is worth noting that there are reports of urgent and emergency situations in which $65 \%$ of the cases do not constitute a true emergency ${ }^{(3)}$.

It is believed that the length of stay of patients in urgent and emergency care should be better studied since there was difficulty in finding studies addressing this subject in the literature.

Noting the unit of destination of patients treated in urgent or emergency care allows us to analyze how the local health system is organized. In the case of this study, the most frequent destination was hospitalization where the service is located. It is important to plan resources that serve to support urgent care both for cases that need hospitalization and those that require outpatient care, that is, the patient cared for in the urgent service requires continuity of treatment in another sphere of the health system.

\section{Final Considerations}

The analysis of data obtained in this study allowed characterizing the profile of clinical visits in the urgent and emergency services in the studied hospital, identifying the patients' city and unit of origin, day, month and period of day where there is more use of the service, length of stay in the unit, reason of discharge and unit of origin, all information that allows the identification of organizational and managerial problems, aiding the development of strategies for the resolution of problems based on identified realities.

It is expected that the results of this study will support the reorganization and management of nursing services in dimensioning human resources, forecasting and providing material and equipment, since knowledge concerning the characteristics of more frequent demand on the unit allows the development and implementation of measures that appropriately meet specific needs.

Considering that unpredictability is inherent to this type of service, one can use this information as a tool to assist organization and management, facilitate the preparation of the work schedule, manage requests for equipment and material, encourage the exchange of information with other health services in the city, reorganize the emergency care micro space in the hospital, and support the management of local health systems. 


\section{References}

1. Mendes EV. Uma agenda para a saúde. São Paulo: Hucitec; 1999.

2. Ministério da Saúde (BR). Secretaria de Atenção à Saúde. Departamento de Atenção Especializada. Regulação Médica das Urgências [internet]. Brasília (DF): Ministério da Saúde; 2006. (Série A. Normas e Manuais Técnicos). [acesso em: 12 mar. 2008]. Disponível em: http://portal.saude.gov.br/portal/ arquivos/pdf/Manual\%20de\%20Regulacao\%20Medica\%20 das\%20Urgencias.pdf

3. Lovalho AF. Administração de serviços de saúde em urgências e emergências. Mundo Saúde. 2004; 28(2):160-71.

4. Rocha AFS. Determinantes da procura de atendimento de urgência pelos usuários nas unidades de Pronto Atendimento da secretaria municipal de saúde de Belo Horizonte [dissertação de mestrado]. Belo Horizonte: Universidade Federal de Minas Gerais; 2005.

5. Chaves LDP. Produção de internações nos hospitais sob gestão municipal em Ribeirão Preto-SP, 1996-2003 [tese de doutorado]. Ribeirão Preto: Escola de Enfermagem de Ribeirão Preto/USP; 2005. 159 p.

6. Chaves LDP, Anselmi ML. Produção de internações hospitalares pelo Sistema Único de Saúde no município de Ribeirão Preto. Rev Gaúch Enferm. 2006;27(4):582-91.

7. Marques GQ, Lima MADS. Demandas de usuários a um serviço de pronto atendimento e seu acolhimento ao sistema de saúde. Rev. Latino-Am. Enfermagem. 2007;15(1):13-9.

8. Fernandes RJ. Caracterização da atenção pré-Hospitalar móvel da secretaria da saúde do município de Ribeirão PretoSP [dissertação de mestrado]. Ribeirão Preto: Escola de Enfermagem de Ribeirão Preto/USP; 2004

9. Garlet ER, Lima MADS, Santos JLG, Marques GQ. Work objective in emergency wards: professionals' conceptions. Rev. Latino-Am. Enfermagem. 2009;17(4):535-40.
10. Dal Pai D, Lautert L. Work under urgency and emergency and its relation with the health of nursing professionals. Rev. Latino-Am. Enfermagem. 2008;16(3):439-44.

11. Franco B, Rabelo ER, Goldemeyer S, Souza EN. Patients with acute myocardial infarction and interfering factors when seeking emergency care: implications for health education. Rev. LatinoAm. Enfermagem. 2008;16(3):414-8.

12. Gentil RC, Ramos LH, WhitakerIY. Nurses'training in prehospital care. Rev. Latino-Am. Enfermagem. 2008;16(2):192-7.

13. Gatti MFZ, Silva MJP. Ambient music in the emergency services: the professionals' perception. Rev. Latino-Am. Enfermagem. 2007;15(3):377-83.

14. Batista KM, Bianchi ERF. Estresse do enfermeiro em unidade de emergência. Rev. Latino-Am. Enfermagem. 2006;14(4):534-9.

15. Conselho Nacional de Saúde (BR). Resolução 196, de 10 de outubro de 1996. Dispõe sobre diretrizes e normas regulamentadoras de pesquisa envolvendo seres humanos. Brasília; 1997.

16. Silva VPM, Silva AK, Heinisch RH, Heinisch LMM.. Caracterização do perfil da demanda da emergência de clínica médica do Hospital Universitário da Universidade Federal de Santa Catarina. Arq Catarin Med. 2007;36(4):18-27.

17. Furtado BM, Alencar SM, Araujo JLC Jr, Cavalcanti P. O perfil da emergência do Hospital da Restauração: uma análise dos possíveis impactos após a municipalização dos serviços de saúde. Rev Bras Epidemiol. 2004;7(3):279-89.

18. Jacobs PC, Matos EP. Estudo exploratório dos atendimentos em unidade de emergência em Salvador-Bahia. Rev. Ass. Med. Bras. 2005; 51(6):348-53.

19. Chaves LDP, Anselmi ML. Explantory factors for the variation in hospitalizations. Rev. Latino-Am. Enfermagem. 2008;16(2):287-92.

Received: Jun. 24th 2009

Accepted: May. $3^{\text {rd }} 2010$ 